УДК 373.3/.5:17.022.1

DOI https://doi.org/10.32782/apv/2021.1.11

\title{
Катерина ДЕСЯТНИК
}

кандидат педагогічних наук, дочент, доцент кафедри теорії і методики початкової освіти, Волинський національний університет імені Лесі Українки, просп. Волі, 13, м. Лущььк, Волинська обл., Україна, 43025 ORCID: 0000-0001-9804-2863

Бібліографічний опис статті: Десятник, К. (2021). Особливості формування іміджу сучасного освітнього закладу. Acta Paedagogica Volynienses, 1, 61-67, doi: https://doi.org/10.32782/apv/2021.1.11

\section{ОСОБЛИВОСТІ ФОРМУВАННЯ ІМІДЖУ СУЧАСНОГО ОСВІТНЬОГО ЗАКЛАДУ}

У сучасному світі проблема формування іміджу освітнього закладу стає актуальною, оскільки у ринкових умовах конкурентоспроможність є головною умовою життєздатності організації. У статті визначено змістову сутність понять «імідж», «імідж освітнього закладу». Розкрито структуру іміджу освітньої організацї (образ керівника, якість освітніх послуг, рівень психологічного комфорту, образ персоналу, стиль освітнього закладу, зовнішня атрибутика, зв 'язки освітнього закладу) та етапи формування позитивного іміджу освітньої установи: діагностика; планування; реалізачія запланованих заходів; моніторинг іміджу; підтримка. Виокремлено заходи формування позитивного іміджу закладу загальної середньої освіти, шляхи його просування. З'ясовано, шуо важливою складовою діяльності освітньої організаиії є розробка PR-стратегї. Наголошено, щчо завданням внутрішнього PR (корпоративного) є створення освітнього середовища: сприятливі відносини керівництва закладу з персоналом на всіх рівнях управління в освітньому просторі, партнерство учасників освітнього процесу, корпоративна культура, традииї закладу, ефективність системи взаємодї підрозділів, мотивачія до трудової діяльності педагогічних праиівників, удосконалення професійної компетентності педагогів, матеріально-технічне та методичне забезпечення, благоустрій будівлі та території школи, щзо забезпечує якість освітньої діяльності та якість освіти. Зовнішній PR охоплює роботу із зовнішнім простором навчального закладу, з партнерами, інвесторами, конкурентами, громадою: створення сприятливого образу закладу та підтримка іміджу й рейтингу закладу; створення сприятливих відносин зі споживачами освітніх послуг; робота із засобами масової інформаиї; робота з державними закладами та громадськими організаціями; проведення презентацій, участь в освітніх виставках, громадських заходах тощзо. Узагальнено, щз забезпечення успіху на ринку освітніх послуг вимагає від закладу освіти пошуку нових технологій, спрямованих на конструювання та підтримку стійкого позитивного іміджу.

Ключові слова: імідж, імідж освітнього закладу, заклад загальної середньої освіти, структура іміджу освітньої організації, заходи формування позитивного іміджу закладу освіти.

\section{Kateryna DESIATNYK}

PhD in Pedagogy, Associate Professor, Senior Lecturer at the Department of Theory and Methods of Primary Education, Lesya Ukrainka Volyn National University, 13 Voli ave., Lutsk, Volyn region, Ukraine, 43025 ORCID: 0000-0001-9804-2863

To cite this article: Desiatnyk, K. (2021). Osoblyvosti formuvannia imidzhu suchasnoho osvitnoho zakladu [Features of formation of the modern educational institution's image]. Acta Paedagogica Volynienses, 1, 61-67, doi: https://doi.org/10.32782/apv/2021.1.11

\section{FEATURESOFFORMATIONOFTHEMODERNEDUCATIONALINSTITUTION'SIMAGE}

The problem of formation of the educational institution's image becomes relevant in today's world, because competitiveness is the main condition for the viability of the organization in market conditions.

The article defines the semantic essence of the concepts «image», «image of the educational institution». The structure of the image of the educational organization (image of the head, quality of educational services, level of psychological comfort, image of staff, style of educational institution, external attributes, connections of educational institution) is explained. Stages of formation of positive image of educational institution are revealed: diagnostics; planning; implementation of planned activities; image monitoring; support are explained. Measures for the formation of a positive image of the institution of general secondary education, ways to promote it are highlighted. It was found that an important component of the educational organization is the development of PR-strategy. It is emphasized that the task of internal $P R$ (corporate) is to create an educational environment: favorable relations of management with staff at all levels of management in the educational space, partnership of participants in the educational process, corporate culture, traditions, 
efficiency of interaction, motivation to work of teachers, improvement of professional competence of teachers, material and technical and methodological support, improvement of the building and territory of the school, which ensures the quality of educational activities and the quality of education. External PR includes work with the external space of the educational institution, with partners, investors, competitors, community: creating a favorable image of the institution and maintaining the image and rating of the institution; creating favorable relations with consumers of educational services; work with mass media; work with government agencies and NGOs; conducting presentations, participation in educational exhibitions, public events, etc. The author generalizes that ensuring success in the market of educational services requires to search for new technologies aimed at designing and maintaining a sustainable positive image.

Key words: image, image of the educational institution, institution of general secondary education, structure of the image of the educational organization, measures of formation of a positive image of the educational institution.

Постановка проблеми. Проблема конкурентоспроможності освітнього закладу, його унікальності особливо актуальна в сучасних ринкових умовах. Життєдіяльність навчального закладу пов'язана зі становленням і розвитком різних напрямів його діяльності й практика управління освітньою організацією показує, що успішне й оптимальне ії функціонування та розвиток неможливе без формування позитивного іміджу. Це змушує керівництво закладів освіти вибудовувати свою діяльність на засадах освітнього менеджменту, дбати про репутацію закладу загальної середньої освіти (3ЗСО), оскільки позитивний імідж освітньої установи приваблює фінансові, трудові, інформаційні ресурси. Заклади освіти зі сформованим позитивним стійким іміджем викликають почуття довіри у батьків, здобувачів освіти, громади, привертають увагу педагогічних працівників, формують тісні зв'язки та партнерство.

Аналіз останніх досліджень та публікацій. Нині все більше зростає інтерес до проблеми формування іміджу освітнього закладу. Конкуренція на ринку освітніх послуг, зокрема, в системі загальної середньої освіти, значно активізувала проведення низки досліджень у даному контексті. Імідж організації вивчається психологами, педагогами, економістами, маркетологами та іншими фахівцями і вченими різних сфер та напрямів діяльності.

Насамперед численні роботи авторів присвячені питанню формування іміджу особистості. Зокрема серед зарубіжних фахівців, що вивчають теоретичні і практичні аспекти формування іміджу особистості, необхідно відзначити таких учених, як П. Берд, З. Блек, Л. Браун, Ф. Буарі, П. Вейл, Т. Парсонс, М. Спіллейн, Т. Сван, Р. Хофф, П. Чисхольм, Б. Швальбе та ін.

Серед наукових робіт щодо становлення індивідуального іміджу людини варто зазначити роботи І. Альохіна, А. Бандурки, М. Бєляєвої, Т. Кизилова, Ф. Кузіна, А. Пелиха, В. Сам- кової та ін., іміджу педагога - В. Бондаренка, Г. Дудчак, А. Кононенка, М. Навроцької, І. Размолодчикової, Л Серман та ін.

Проблеми формування іміджу освітньої організації досліджують Т. Антоненко, I. Єрмаков, А. Головченко, В. Григораш, Є. Зуєва, І. Зуєвська, Л. Карамушка, М. Піскунов, Т. Піскунова, Л. Присяжнюк, О. Ткаченко, I. Топчій та ін.

Питання розвитку організації та управління закладом освіти вивчаються Ю. Конаржевским, В. Лазарєвим, В. Лунячеком, О. Мармазою, М. Поташником, $€$. Хриковим та ін.

Метою статті $є$ аналіз деяких теоретичних та практичних аспектів формування позитивного іміджу закладу загальної середньої освіти.

Виклад основного матеріалу дослідження. Перш ніж говорити про імідж освітньої установи і особливості його формування, необхідно уточнити зміст поняття «імідж». Різні джерела подають неоднозначні визначення даної категорії.

У Словнику іншомовних слів поняття «імідж» (з англ. image - образ) визначається як показ, зображення, зразок; уявний образ, уявлення; формування стійкого позитивного враження про товар, послуги підприємства [1, с. 257]; Український тлумачний словнику трактує імідж як «рекламний, представницький образ кого-небудь (наприклад, громадського діяча), що створюється для населення» [2, с. 396]; Словник психолога-практика - як емоційно забарвлений образ когось або чогось, який склався в масовій свідомості та має характер стереотипу. Формування іміджу відбувається стихійно, але найчастіше це - результат роботи фахівців у галузі психології політичної, психології реклами, маркетингу та ін. [3]; Словник із соціології - як образ, зображення; реальне (або уявне) обличчя, стиль ділової поведінки людини, підприємця, фірми, ставлення до них на основі їх популярності та успіху, довір'я і симпатії людей; основа формування іміджу оцінка результатів діяльності [4, с. 118]; 
Педагогічний енциклопедичний словник вказує, що імідж - це цілеспрямовано формований образ (якоїсь особи, явища, предмета), покликаний справити емоційно-психологічний вплив на когось 3 метою популяризації, реклами тощо [5, с. 103]; у посібнику з імеджіології імідж розглядається як образ, сукупність характеристик, які оцінюються суспільством і в результаті формується думка про когось або щось, ставлення до когось, чогось. Поняття «образ» не синонімічне поняттю «імідж», тому що образ в описі суб'єкта або об'єкта відображає насамперед зовнішній візуальний ряд, а імідж має й інші складові. Імідж - це певний набір знаків, що в сумі утворюють «повідомлення» («message»), яке сприймається цільовою аудиторією (референтною групою) однозначно [6, с. 20; 6].

Отже, імідж - це образ, уявлення про людину, предмет, явище, інститут тощо, покликаний справити емоційно-психологічний вплив на певну аудиторію, сформувати стійке позитивне враження.

Під іміджем навчального закладу О. Язловецька розуміє емоційно забарвлений образ, який утворився у масовій свідомості, що володіє цілеспрямовано заданими характеристиками і покликаний чинити психологічний вплив певної спрямованості на конкретні групи соціального оточення загальноосвітнього закладу [7, c. 235].

У контексті проблеми дослідження I. Топчій трактує імідж освітнього закладу як певний емоційно-забарвлений образ, що характеризується співвідношенням ціннісних настанов і очікувань особистості, транслюється у соціальне середовище та формує модель конкурентоспроможності. Тобто, імідж розуміється як думка групи людей про освітній заклад на основі сформованого образу, що виник унаслідок або безпосереднього досвіду взаємодії 3 ним, або в результаті інформації, отриманої від інших людей [8, с. 179].

Л. Присяжнюк, Т. Кук вважають, що імідж закладу освіти доцільно трактувати як спеціально створений образ, який наділений певними цінностями, Значущими для об'єкта впливу [9, с. 20].

О. Ткаченко зазначає, що головне завдання іміджу полягає у формуванні позитивного ставлення до закладу освіти в цілому, його колективу та результатів його діяльності. Це формує довіру до освітньої установи, що проявляється у високих оцінках і виборі ii 3-поміж інших подібних [10, с. 98]

Таким чином, імідж освітнього закладу - це загальне уявлення, утворене з низки відчуттів і переконань, яке складається у різних категорій споживачів освітніх послуг, як реальних так і потенційних. Водночас структура іміджу школи включає:

1. Позитивний образ керівника освітньої організації (його особистісні, професійні, фізичні та психологічні особливості й якості). До таких характеристик відносяться: характер, освіта, культура, привабливість, біографія, статус, поведінка, цінності, переконання, знання технологій виховання і навчання, основ розвитку організації тощо. Збірний образ керівника освітнього закладу являє собою лідера, яскраву особистість, що користується авторитетом в колективі, здатний надихати і мотивувати співробітників на досягнення результатів у роботі.

2. Якість освітніх послуг - це кінцева ціль освіти і виховання здобувачів, місія освітньої установи. Формування стійкої якості освітніх послуг вимагає від закладу вагомого внеску в процеси розвитку навчання і виховання учнів, ïx психічного і фізичного здоров'я, здібностей, творчого мислення, соціальної адаптації тощо.

3. Рівень психологічного комфорту передбачає створення безпечного освітнього середовища, доброзичливу атмосферу в колективі, оптимістичне налаштування педагогів, безконфліктні взаємини вчителя з учнями, повагу та ін.

4. Образ персоналу складають такі елементи, як особистісні якості працівників, рівень їх кваліфікації, педагогічна, управлінська компетентність, професіоналізм, зовнішній вигляд тощо.

5. Стиль освітнього закладу включає організаційну культуру, традиції освітнього закладу, певні цінності, норми, філософію управління, взаємини особливості поведінки колективу тощо.

6. Зв'язки освітнього закладу з партнерами, клієнтами та іншими соціальними інститутами тощо.

7. Зовнішня атрибутика (яскрава символіка) - це наявність фірмового стилю, газети, власного Інтернет-сайту, шкільної форми, дрес-коду [11, с. 132].

Аналізуючи структуру іміджу освітнього закладу, виділяємо дві основні його складові: внутрішній імідж (суб'єкт сприйняття - 
персонал організації) та зовнішній імідж (імідж організації в очах партнерів, споживачів, конкурентів тощо).

Імідж освітнього закладу не є сталим. Його формування відбувається протягом тривалого часу, а сформований імідж коригується під впливом вражень споживачів освітніх послуг, батьків, педагогів, партнерів та інших. Тому важлива системність та чітка послідовність у процесі формування та підтримки іміджу.

Виокремлюють такі етапи формування іміджу підприємства сфери послуг [12, с. 160]:

Дослідження іміджу: аналіз стратегії розвитку підприємства, напрямів іiі реалізації; визначення цільової аудиторії підприємства, іiі основних характеристик і переваг; оцінювання іміджу підприємства і визначення напрямів його покращення; визначення іміджевої стратегії конкурентів; аналіз об'єкта формування іміджу та параметрів формування іміджу.

Розробка стратегіі управління іміджем: формування концепції і стратегії управління іміджем; формування політики управління іміджем підприємства; визначення особливостей інформаційної кампанії щодо іміджу підприємства (інструменти, канали і методи взаємодії з цільовою аудиторією); визначення ризиків i варіантів розвитку PR-заходів і рекламної кампанії щодо управління іміджем;

Реалізація стратегії управління іміджем: впровадження заходів щодо формування іміджу підприємства; збирання і аналіз даних щодо виявлення динаміки руху іміджу; формування критеріїв вимірювання іміджу; оцінювання змін іміджу підприємства за результатами впроваджених заходів.

Моніторинг іміджу: аналіз думок, настанов та шаблонів сприйняття іміджу підприємства; виявлення негативних чинників сприйняття іміджу та планування заходів щодо їх усунення; розробка цілеспрямованих заходів щодо корегування іміджу.

Підтримка: розвиток, корегування та підтримка іміджу підприємства; управління соціально-економічними трансформаціями господарських процесів: реалії і виклики

Порядок етапів формування іміджу має важливе значення, оскільки визначає не тільки швидкість формування та рівень іміджу, а також впливає на бюджет рекламних та інших маркетингових заходів підприємства.
Етапність формування іміджу освітнього закладу має таку ж логіку і послідовність. Зокрема О. Язловецька [7] вирізняє п'ять етапів формування іміджу закладу загальної середньої освіти. І етап - визначення місії. Починати потрібно $з$ аналізу зовнішнього середовища. Спочатку варто визначитися 3 базовою ідеєю («концепцією», «місією», «родзинкою»). Підсумком цього етапу має бути чітке розуміння того, які ваші сильні та слабкі сторони. II етап визначення цільової аудиторії. Плануючи іміджеву роботу, необхідно зрозуміти, на яку цільову аудиторію ви орієнтуєтесь. До цільової аудиторії в сфері освіти належать: батьки, учні, педагоги, персонал закладу, представники органів влади. III етап - планування. Розробка конкретних заходів, пов'язаних з формуванням іміджу. IV етап: реалізація запланованих заходів. Найважливіше у здійсненні будь-яких дій по формуванню іміджу $33 \mathrm{CO}$ - це їх органічна інтеграція в освітній процес. V етап - перевірка ефективності. На цій стадії, зазвичай, щорічно проводиться аналіз відповідності отриманого іміджу з бажаним результатом.

На основі аналізу наукових досліджень $[7 ; 8 ; 9 ; 11 ; 12]$ ми виділяємо такі етапи процесу формування іміджу освітньої організації: діaгностика; планування; реалізація запланованих заходів; моніторинг іміджу; підтримка.

На першому діагностичному етапі здійснюється цілеспрямована робота 3 дослідження іміджу освітньої установи, що передбачає:

- формулювання місії освітньої організації, визначення перспектив освітньої діяльності педагогічним колективом, цілей, складання плану діяльності;

- аналіз стратегії розвитку освітнього закладу;

- визначення цільової аудиторії;

- аналіз очікувань батьків і здобувачів освіти;

- оцінювання іміджу організації й визначення напрямів його покращення;

- аналіз організаційної культури освітньої організації, системи іiі цінностей, традицій, норм, звичаїв, поведінки, взаємин, ритуалів, церемоній;

- вироблення власного стилю (зовнішня символіка освітньої установи, етика взаємодії в педагогічному колективі).

Стадія планування передбачає розробку стратегії управління іміджем, конкретних заходів 
3 формування іміджу. Основними завданнями створення зовнішнього іміджу є наступні дії:

- розробка (коригування) елементів зовнішньої атрибутики освітнього установи 3 метою масової демонстрації, підвищення упізнаваності на ринку освітніх послуг, формування корпоративності;

- розробка реклами з метою вираження своєї унікальності і демонстрації якості пропонованих послуг;

- активна пропаганда досягнень навчального закладу в соціальних мережах, на телебаченні тощо (рейтинг закладу за результатами ЗНО, результативність вступу випускників до закладів вищої освіти, високий рівень освітніх і управлінських процесів за результатами інституційного аудиту, якісний показник участі учнів школи в предметних олімпіадах, конкурсах-захистах науково-дослідних робіт, творчих конкурсах, спортивних змаганнях, турнірах);

- створення та підтримка Web-сайту (з різними розділами: «Інформація про школу», «Правила вступу до закладу освіти», «Новини», «Освітній процес», «Дистанційне навчання», «Шкільне самоврядування», «Рекомендації для батьків», «Фотогалерея» та інші);

- створення реклами освітнього закладу (сувенірна продукція, листівки, бюлетені, буклети, рекламні ролики на телебаченні та ін.);

- налагодження зв'язків з громадськістю, організація PR-заходів;

- участь у масштабних проєктах, дослідженнях, волонтерській діяльності.

Завданнями створення внутрішнього іміджу освітньої установи є:

- створення корпоративного духу за допомогою зміцнення традицій в колективі;

- фірмовий знак, система заохочень, відзначення і увага до особистих свят (день народження та ін.);

- шанобливе ставлення до гостей та відвідувачів;

- створення сприятливого іміджу, системи стимулювання працівників за допомогою впровадження соціальних, психологічних і економічних механізмів мотивування та підвищення зацікавленості співробітників освітнього установи;

- формування сучасного іміджу кожного педагога;

- загальний стиль оформлення приміщень навчального закладу;
- зовнішня атрибутика;

- проведення додаткових заходів для аудитоpiї (збори, семінари, конференції, дні відкритих дверей);

- соціальна реклама конкретної важливої суспільно значущої діяльності;

- організація зворотного зв 'язку з випускниками.

Дані заходи дозволять кожному співробітнику відчути себе частиною колективу, бути потрібним у цьому колективі і прагнути відповідати йому.

Третій етап - реалізація плану є найважливішим у формуванні іміджу освітньої установи, він забезпечує впровадження програми й проведенні заходів.

Наступний етап, моніторинг іміджу - це перевірка ефективності, аналіз сприйняття іміджу закладу. Рекомендується таку перевірку проводити не рідше ніж один раз на рік, за підсумками якої необхідно давати оцінку відповідності сформованого іміджу запланованим заходам і кінцевому результату. Обов'язкова умова при цьому - оформлення результатів моніторингу, доведення їх до педагогічного персоналу, розробка цілеспрямованих заходів корегування іміджу, усунення негативних чинників сприйняття іміджу закладу.

Завершальний етап, підтримка, охоплює розвиток, коригування, підтримку і оновлення створеного іміджу освітньої організації. Основні завдання даного етапу:

- стимулювання інноваційної діяльності. Важливо задіяти педагогічний персонал у різних додаткових напрямках навчання, підготовки і перепідготовки (курси підвищення кваліфікації, перепрофілювання, конкурси, сертифікація вчителів та ін.);

- створення новаторських напрямків діяльності;

- введення нових освітніх послуг;

- організація постійної роботи з підтримки зв'язку з партнерами і споживачами освітніх послуг (з батьками, учнями тощо).

Також важливими заходами для створення i підтримки позитивного іміджу освітнього закладу є благоустрій будівель і території установи освіти, постійне оновлення та удосконалення матеріально-технічної бази та навчальнометодичного забезпечення, проведення презентацій, виставок, створення Інтернет публікацій та постів у соціальних мережах. 
Сформований і відкоригований імідж школи сприяє зростанню привабливості закладу для потенційних споживачів освітніх послуг (в першу чергу, для учнів, їх батьків і персоналу); підвищенню ефективності рекламних та інформаційних заходів щодо якості освітніх послуг; покращенню психологічного клімату в колективі; розвитку рівня організаційної культури.

Створення іміджу є однією із задач паблік рилейшнз (PR) - науки і мистецтва, функції управління, яка сприяє встановленню і підтриманню спілкування, взаєморозуміння, співробітництва між організацією і громадськістю.

Тому важливою складовою діяльності закладу освіти є розробка PR-стратегії [7; 9]. Завдання внутрішнього PR (корпоративного) полягає у створенні освітнього середовища: сприятливі відносини керівництва закладу 3 персоналом на всіх рівнях управління в освітньому просторі, партнерство учасників освітнього процесу, корпоративна культура, традиції закладу, ефективність системи взаємодії підрозділів, мотивація до трудової діяльності педагогічних працівників, удосконалення професійної компетентності педагогів, матеріально-технічне та навчально-методичне забезпечення, благоустрій будівлі та території школи тощо, що забезпечує якість освітньої діяльності та якість освіти. Зовнішній $\mathrm{PR}$ - це робота із зовнішнім простором навчального закладу, з партнерами, інвесторами, конкурентами, громадою: створення сприятливого образу закладу та підтримка іміджу й рейтингу закладу; антикризовий менеджмент; створення сприятливих відносин зі споживачами освітніх послуг; робота із засобами масової інформації, $з$ державними закладами та громадськими організаціями; проведення презентацій, участь в освітніх виставках, громадських заходах тощо.

Отже, забезпечення успіху на ринку освітніх послуг вимагає від закладу освіти пошуку інноваційних механізмів формування позитивного іміджу. Керований імідж - це результат складної, добре виваженої діяльності, спрямованої на створення, підтримку та посилення позитивної громадської думки про освітню організацію у взаємодії закладу з фахівцями 3 просування.

Висновки. Таким чином, перед освітнім закладом стоїть важливе завдання - створення і розвиток позитивного іміджу шляхом цілеспрямованого впливу різноманітних маркетингових, інформаційних або PR заходів, інтегрування нових ідей щодо надання освітніх послуг, підвищення рейтингу в сучасному конкурентному освітньому просторі.

\section{ЛІТЕРАТУРА:}

1. Шевченко Л. І., Ніка О. І., Хом'як О. І., Дем'янюк А. А. Новий словник іншомовних слів : близько 40000 слів і словосполучен / за ред. Л. І. Шевченко. Київ : АРІЙ, 2008. 672 с.

2. Великий тлумачний словник сучасної української мови / уклад. і гол. ред. В. Т. Бусел. Київ - Ірпінь: ВТФ Перун, 2002. 1440 c.

3. Словарь психолога-практика; сост.: С. Ю. Головин. 2-е изд., перераб. и доп. Минск : Харвест, Москва : ACT, $2001.976 \mathrm{c}$.

4. Соціологія: словник термінів і понять / упоряд. : Біленький Є. А., Дебой В.М., Козловець М.А., Котвицький А.А., Саух І.В., Федоренко В. О., Цибульський В.О., Жаловага В.О. / за заг. ред. : Біленького Є.А. і Козловця М.А. Київ: Кондор, 2006. 372 с.

5. Педагогический энциклопедический словарь / гл. ред. Б. М. Бим-Бад ; редкол. : М. М. Безрукич, В. А. Болотов, Л. С. Глебова и др. Москва : Большая Российская энциклопедия, 2003. 528 с.

6. Беляева М.А., Самкова В.А. Азы имиджелогии: имидж личности, организации, территории: учебное пособие для вузов. Екатеринбург : Урал. гос. пед. ун-т., 2016. 184 с.

7. Язловецька О. В. Зміст роботи загальноосвітнього навчального закладу щодо формування позитивного іміджу. Наукові записки КДПУ. Сер. Педагогічні науки. Кіровоград: КДПУ, 2014. Вип. 125. С. 234-240.

8. Топчій І.В., Бегеза Л.Є. Психолого-педагогічні засади конкурентоспроможності закладу освіти у нових соціокультурних умовах. Вісник Чернігівського національного педагогічного університету ім. Т.Г. Шевченка. Чернігів, 2014. Вип. 121, т. 2. С. 178-181.

9. Присяжнюк Л. А., Томаш Кук. Формування позитивного іміджу закладу загальної середньої освіти в контексті його інноваційного розвитку. Молодий вчений. 2019. № 5.2 (69.2), травень. С. 19-25.

10. Ткаченко О. О. Імідж навчального закладу : поняття та сутність. Бібліотекознавство. Документознавство. Інформологія. 2016. № 1. С. 95-101. 
11. Джабраилова Л. Х., Джапаева Й. В. Имидж образовательной организации как фактор повышения привлекательности на рынке образовательных услуг. Известия Чеченского государственного педагогического института. 2019. T. 25. № 3 (27). C. 129-136.

12. Рубіш М. А. Імідж підприємства сфери послуг: його роль та етапи формування. Управління соиіальноекономічними трансформачіями господарських процесів: реалї і виклики: збірник тез доповідей Міжнародної науково-практичної конференції (м. Мукачево, 18-19 квітня 2019 р.). Мукачево: МДУ, 2019. 361 с. С. 159-161.

\section{REFERENCES:}

1. Shevchenko L. I., Nika O. I., Khomiak O. I., Demianiuk A. A. (2008) Novyi slovnyk inshomovnykh sliv : blyzko 40000 sliv i slovospoluchen [New dictionary of foreign words: about 40,000 words and phrases]. L. I. Shevchenko (Ed.). Kyiv : ARII [in Ukrainian].

2. Busel V. T. (Ed.). (2002) Velykyi tlumachnyi slovnyk suchasnoi ukrainskoi movy [Large explanatory dictionary of the modern Ukrainian language]. Kyiv - Irpin: VTF Perun [in Ukrainian].

3. Holovyn S. Yu. (Ed.). (2001) Slovar psykholoha-praktyka [Practical Psychologist Dictionary]. (2 ${ }^{\text {nd }}$ ed., rev.). Mynsk : Kharvest, Moskva : AST [in Russian].

4. Bilenkoho Ye.A. \& Kozlovtsia M.A. (Eds.) (2006). Sotsiolohiia: slovnyk terminiv i poniat [Sociology: a dictionary of terms and concepts]. Kyiv: Kondor [in Ukrainian].

5. Bym-Bad B. M. (Ed.). (2003) Pedahohycheskyi эntsyklopedycheskyi slovar [Pedagogical encyclopedic dictionary]. Moskva : Bolshaia Rossyiskaia эntsyklopedyia [in Russian].

6. Beliaeva, M.A., \& Samkova, V.A. (2016) Azы ymydzhelohyy: ymydzh lychnosty, orhanyzatsyy, terrytoryy: uchebnoe posobye dlia vuzov [The basics of imageology: the image of a person, organization, territory: a textbook for universities]. Ekaterynburh : Ural. hos. ped. un-t. [in Russian].

7. Yazlovetska O. V. (2014) Zmist roboty zahalnoosvitnoho navchalnoho zakladu shchodo formuvannia pozytyvnoho imidzhu [The content of the work of a secondary school as to formation of a positive image]. Naukovi zapysky KDPU. Ser. Pedahohichni nauky. Kirovohrad: KDPU, issue 125. P. 234-240 [in Ukrainian].

8. Topchii I.V., \& Beheza L.Ye. (2014) Psykholoho-pedahohichni zasady konkurentospromozhnosti zakladu osvity u novykh sotsiokulturnykh umovakh [Psychological and pedagogical principles of competitiveness of educational institution in the new socio-cultural conditions]. Visnyk Chernihivskoho natsionalnoho pedahohichnoho universytetu im. T.H. Shevchenka. Chernihiv, issue 121, Vol. 2. P. 178-181 [in Ukrainian].

9. Prysiazhniuk L. \& A., Tomash Kuk. (2019) Formuvannia pozytyvnoho imidzhu zakladu zahalnoi serednoi osvity $\mathrm{v}$ konteksti yoho innovatsiinoho rozvytku [Formation of positive image of general secondary education in the context of its innovation development]. Molodyi vchenyi. No. 5.2 (69.2), May. P. 19-25 [in Ukrainian].

10. Tkachenko O. O. (2016) Imidzh navchalnoho zakladu : poniattia ta sutnist [The image of the educational institution: concept and essence]. Bibliotekoznavstvo. Dokumentoznavstvo. Informolohiia. No. 1. P. 95-101 [in Ukrainian].

11. Dzhabraylova L. Kh., \& Dzhapaeva Y. V. (2019) Ymydzh obrazovatelnoi orhanyzatsyy kak faktor povyshenyia pryvlekatelnosty na ronke obrazovatelnыkh usluh [The image of the educational organization as a factor in increasing the attractiveness of the educational market]. Yzvestyia Chechenskoho hosudarstvennoho pedahohycheskoho ynstytuta. Vol. 25. \# 3 (27). P. 129-136 [in Russian].

12. Rubish M. A. (2019) Imidzh pidpryiemstva sfery posluh: yoho rol ta etapy formuvannia [The image of the enterprise in the field of services: its role and stages of formation]. In: Mukachevo State University, Management of socio-economic transformations of business processes: realities and challenges, Proceedings of the International Conference, Mukachevo, April 18-19 2019. Mukachevo, P. 159-161 [in Ukrainian]. 